\title{
Physical Control of Nonindigenous Aquatic Plants in Emerald Bay, Lake Tahoe, CA
}

\author{
Daniel W. H. Shaw, Zachary P. Hymanson, and Tamara L. Sasaki*
}

\begin{abstract}
Establishment of nonindigenous (NI) aquatic plants in the nearshore regions of freshwater ecosystems has resulted in environmental degradation, recreation concerns, economic impacts, and substantial management challenges. To reduce these undesirable effects, NI aquatic plants are often targeted for removal or control by management agencies, but the efficacy of implementation is often not documented or sustained. In this study, we developed a management plan to completely remove all NI plants from Emerald Bay, Lake Tahoe, CA, using only physical control techniques. Management plan priorities were based on previous research and lessons learned, including the need for (1) integrated weed management using multiple physical control techniques, (2) a large initial treatment investment, (3) ongoing early detection and rapid response, (4) detailed ecological monitoring, and (5) a long-term commitment to annual maintenance removal. Application of this management plan resulted in complete removal of all NI aquatic plants from Emerald Bay and substantial cost savings each year after the initial large investment. Annual maintenance removal and monitoring will need to continue as long as NI aquatic plants continue to enter Emerald Bay on boats and currents from other areas of Lake Tahoe.
\end{abstract}

Key words: Benthic barriers, diver-assisted suction removal, early detection, integrated weed management, rapid response, Lake Tahoe.

NI aquatic plants can alter the character and quality of a waterbody, and their establishment in the United States has resulted in a number of ecological and recreational impacts (Boylen et al. 1999; Bremigan et al. 2005; Landers 1982; Madsen et al. 1991; Smith and Adams 1986; Smith and Barko 1990) as well as economic impacts incurred from reduced property values (Halstead et al. 2003; Horsch and Lewis 2008; Zhang and Boyle 2010). To limit these effects, NI aquatic plants are often targeted for removal and control by resource managers.

In the Lake Tahoe, CA, region, establishment of NI aquatic plants has been implicated in (1) nutrient mobilization into surrounding waters, which can support increased production of periphyton and phytoplankton (Walter 2000); (2) creating new habitat that can facilitate the spread of undesirable NI fish and invertebrates (Kamerath et al. 2008; Tucker et al. 2010); (3) preconditioning nearshore areas for further NI species establishment through alterations in the substrate and other

\section{DOI: 10.1614/IPSM-D-16-00005.1}

* First and third author: Environmental Scientist and Senior Environmental Scientist, California State Parks, Sierra District, P.O. Box 266, Tahoma, CA 96142; second author: Associate Director, Tahoe Environmental Research Center, University of California, Davis, 291 Country Club Drive, Incline Village, NV 89451. Corresponding author’s E-mail: daniel.shaw@parks.ca.gov habitat conditions (Barko and Smart 1980; Heyvaert et al. 2013); and (4) altering aquatic ecosystems, leading to degraded natural resources and recreation experiences that could cause economic loss from reduced human use (Eisworth et al. 2000).

A number of treatment methods have been used to remove or control populations of NI aquatic plants throughout North America, including chemical, biological, and physical techniques. Specific methods have included the use of aquatic herbicides, weevil or other biological introductions, dredging, colored dyes, shading, water-level manipulation, mechanical harvesting, hand-pulling, diverassisted suction removal, and covering plants to exclude sunlight (Bailey and Calhoun 2008; Laitala et al. 2012; Madsen 1997).

Some water bodies, particularly those that supply drinking water, are limited to treatment options that do not include chemical or biological introductions because of environmental regulations and societal concerns over potential ecological or human health impacts (Bailey and Calhoun 2008; Reylea 2005; Relyea and Hoverman 2006; Wagner et al. 2008). Regional regulations that prohibited the use of pesticides in Lake Tahoe (LRWQCB 1995) and California State Parks environmental management decisions resulted in the exclusive use of benthic barriers, diverassisted suction removal, and diver removal by hand as the 


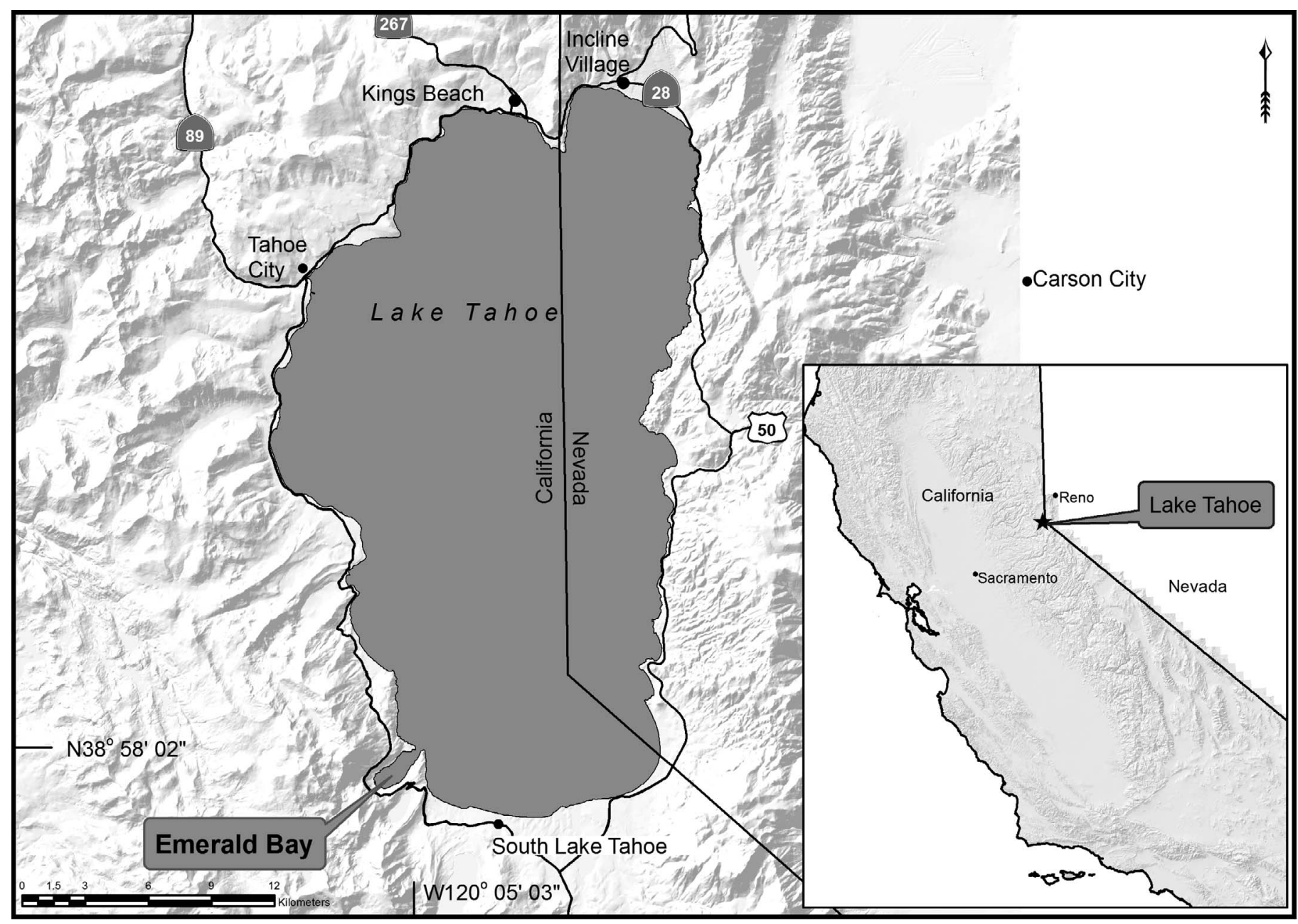

Figure 1. Map of Emerald Bay, Lake Tahoe, CA.

three physical treatment methods for the control of NI aquatic plants in this study.

Several researchers have assessed the effectiveness of different physical treatment methods to control NI aquatic plants (Bailey and Calhoun 2008; Boylen et al. 1996; Eichler et al. 1993; Engel 1984; Kelting and Laxson 2010; Laitala et al. 2012; Perkins et al. 1980) and have found variable levels of control. Challenges and recommendations highlighted in these studies were often similar, finding that initial investment costs were high, efficacy was short lived because of recolonization, new sites continued to become established, multiple treatment tools were important, and that a long-term commitment would be necessary.

To respond to a rapid expansion of NI aquatic plants in Emerald Bay (Lake Tahoe, CA), we incorporated the recommendations highlighted by these researchers to develop a management plan focused on a large scale and long-term, physical-control effort. Our planning effort also benefited from lessons learned during our ecological monitoring and pilot treatment projects and from our science and management collaboration. Our management plan was based on (1) an integrated weed-management strategy using multiple physical control techniques, (2) commitment to a large initial investment toward complete removal of all NI aquatic plants at one discrete site per year, (3) early detection and rapid response (EDRR) to quickly treat new or satellite sites (NISC 2003), (4) long-term and detailed ecological monitoring that was not contingent on implementation funding, and (5) sustaining the progress from past control efforts with annual maintenance treatment. This article details the results of a comprehensive NI aquatic-plant control case study in Emerald Bay.

\section{Materials and Methods}

Study Area. Bisecting the boundary of the states of California and Nevada (Figure 1), Lake Tahoe is the 11thdeepest lake in the world, with a total volume of $156 \mathrm{~km}^{3}$ $\left(37.43 \mathrm{mi}^{3}\right)$. Lake Tahoe was historically an ultraoligotrophic waterbody with low primary productivity and very 
low historical cover of native macrophytes in shallow nearshore areas (Loeb and Hackley 1988; Heyvaert et al. 2013). Well known for its brilliant blue color and water clarity, Lake Tahoe's condition has been challenged in recent decades from chronic loading of nutrients and fine sediment and documented increases in water temperature (Coats et al. 2006; Goldman 1988; Reuter et al. 2009; Sahoo et al. 2016). The introduction and spread of NI aquatic plant species is one management challenge that has accompanied increased nutrient loads and changing water temperatures.

Emerald Bay is located in the southwest corner of Lake Tahoe, El Dorado County, CA (Figure 1). It has an overall length of approximately $2.5 \mathrm{~km}(1.6 \mathrm{mi})$ and approximately $6.25 \mathrm{~km}$ of shoreline, a maximum depth of $63 \mathrm{~m}$ $(207 \mathrm{ft})$, and a total surface area of approximately 1.92 million $\mathrm{m}^{2}\left(20.7\right.$ million $\left.\mathrm{ft}^{2}\right)$. Emerald Bay's surface elevation is about $1,898 \mathrm{~m}$ above sea level. Eagle Creek is the main tributary to Emerald Bay, although several seasonal streams also provide freshwater inputs. A shallow, broad shelf at the eastern end of the bay allows for perpetual water exchange with Lake Tahoe. The entire bay and surrounding land is managed by California State Parks as Emerald Bay State Park. These characteristics provide a bounded system under the control of a single management agency, which streamlined development of a control plan. Emerald Bay is recognized as a National Natural Landmark (NPS 2014) and is the primary boating destination in Lake Tahoe (Wittmann et al. 2015), so negative impacts to local and regional tourism and recreation from the establishment and spread of aquatic plants are of heightened concern.

NI Aquatic Plants. Two species of NI aquatic plants were found in Emerald Bay. Eurasian watermilfoil (Myriophyllum spicatum L.; hereafter, EWM) is a fast-growing plant native to Europe, Asia, and Northern Africa. It has become one of the most detrimental, submerged aquatic plants in North America (Smith and Barko 1990). Although EWM may have been present in marinas in Lake Tahoe as early as the 1970s, it was slow to spread appreciably outside of those sheltered marina areas. EWM was not documented in Emerald Bay until 1995, when only a few stems were present (Anderson 2006; Kim and Rejmankova 2001). EWM spread gradually for $10 \mathrm{yr}$ in Emerald Bay to cover approximately 0.4 ha $(0.99$ acre) by 2005 (Anderson 2006). By 2010, cover of EWM had increased more than sixfold, with total coverage of over 2.4 ha (Figure 2). Curlyleaf pondweed (Potamogeton crispus L.; hereafter, CLP), also native to Europe and Asia, was first documented on the south shore of Lake Tahoe in 2003, and it was reported to occur in Emerald Bay by 2006 (Anderson 2006).
Ecological Monitoring. We established an ecological monitoring program that was focused on the long-term assessment of implementation efforts, remained independent of implementation funding, and was conducted through collaboration between scientists and managers (Lindenmayer and Likens 2010). Ecological monitoring was initiated $2 \mathrm{yr}$ before development and implementation of our management plan and continued throughout the duration of control efforts in Emerald Bay. This monitoring program was used to track changes in plant cover and density over time, to determine the efficacy of small-scale pilot and limited-treatment efforts, to determine material costs, and to track diver effort. We did not have a long-term control site because the intention of the management effort was to completely remove all NI plants from Emerald Bay. Spring sampling occurred before treatment activities scheduled to occur in a particular year, whereas fall sampling occurred after the annual treatment efforts were completed.

Monitoring data (plant cover and density) were collected from 40- to 50-m-long permanent transects established at each site.

Vegetative Cover Estimates. To determine areal coverage of the EWM and CLP in Emerald Bay, we conducted a complete survey of the nearshore area using scuba, snorkel, and visual documentation of unvegetated segments, using an Aquascope ${ }^{\mathrm{TM}}$ (Water Monitoring Equipment and Supply) from a boat during 2010, 2014, and 2015. We also completed a focused scuba and snorkel survey of the west end of Emerald Bay in 2012. All the NI aquatic plant growth occurred at depths ranging from approximately 1 to $8 \mathrm{~m}$. NI aquatic plants were found at the western end of Emerald Bay in a 2.4 ha area, and the perimeter edges of plant patches at each site were recorded using a hand-held global positioning system.

Initially, three discrete infestation areas were identified as Avalanche, Vikingsholm, and Parson's Rock (Figure 2). Two additional satellite sites were detected during EDRR surveys during subsequent years, and these sites were identified as Parson's Rock East and Eagle Creek (Figure 2). Field survey results were visualized in ArcGIS (ESRI, 380 New York Street, Redlands, CA 92373-8100) with georectified satellite images.

Vegetative cover within each site was estimated by the point-intercept method (Elzinga et al. 2001). A diver would note the material present (plant, sediment, log, rock) directly below the transect line at 2-m intervals. NI aquatic plants were tallied as 0 for absent and 1 for present. Maximum shoot height (in centimeters) was measured each time a plant was encountered. Percentage of cover was estimated as (No. of plants/Total No. of points sampled) $\times$ 


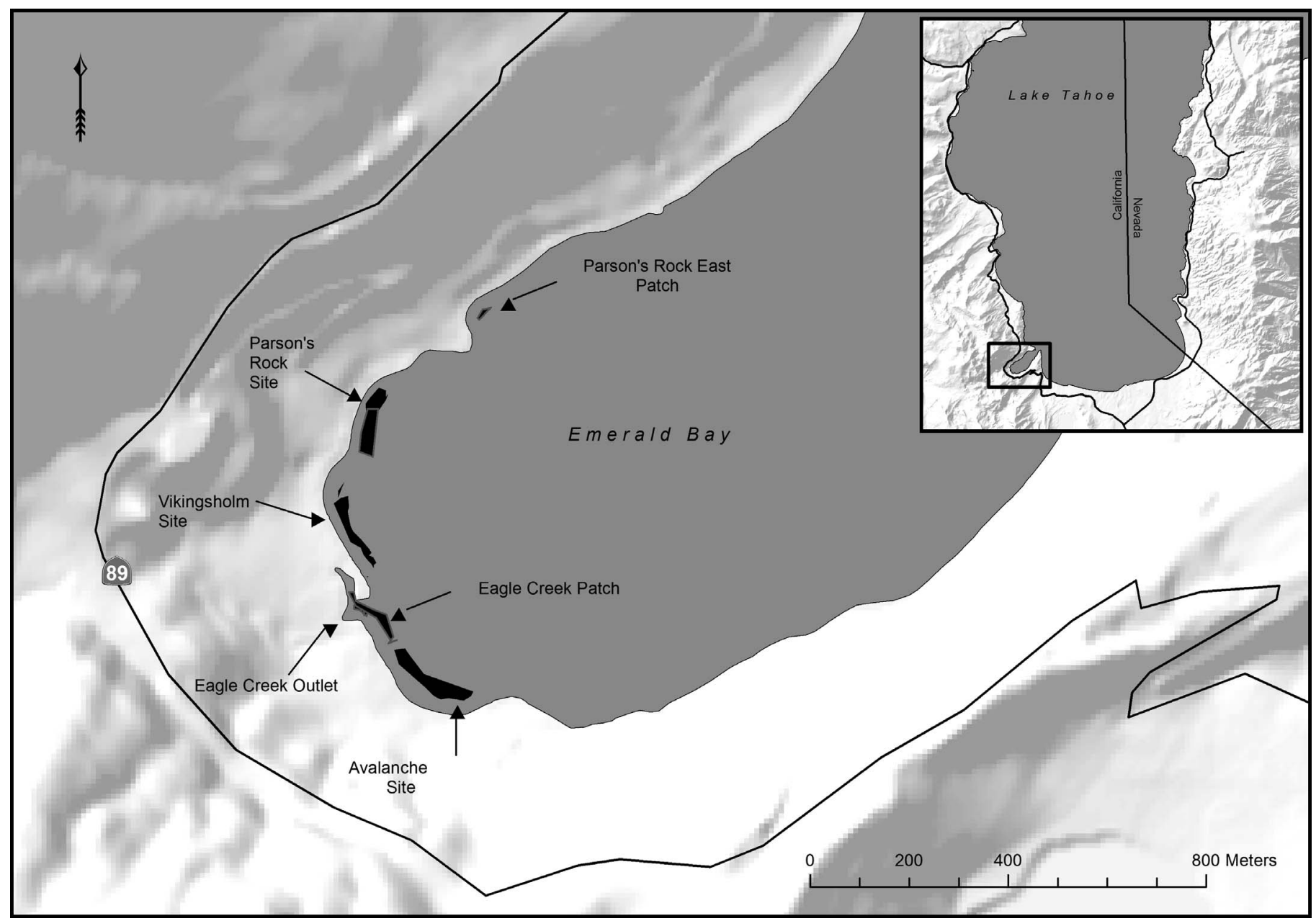

Figure 2. Location of three discrete Eurasian watermilfoil treatment sites (Avalanche, Vikingsholm, and Parson's Rock) and two Eurasian watermilfoil satellite sites (Eagle Creek and Parson’s Rock East) in Emerald Bay State Park.

100. A chi-square test was used to compare the effectiveness of limited treatment (incomplete treatment at Parson's Rock in 2010 and Avalanche in 2011 because of lack of time and funding necessary to remove all plants from the infestations) in terms of percentage of cover the following spring vs. complete weed removal at those sites in future years (Parsons 2001).

Density Estimates. Plant density was estimated by counting each discrete, rooted milfoil cluster in $0.25-\mathrm{m}^{2}$ quadrats placed at preselected, random points along the length of each transect. Local spread of milfoil in Emerald Bay is primarily through stolon production, making differentiation between plants difficult, and clusters emerging from the sediment often had multiple shoots and low, branching stems. We assumed that every discrete cluster within the sampling area represented one individual, and we counted one shoot per cluster. A rooted stolon with a single shoot separated from other shoots was counted as a discrete individual. We established this method to increase diver safety: reducing the bottom-time necessary to complete sampling in this high-elevation, cold-water system. The total number of shoots within each $0.25-\mathrm{m}^{2}$ quadrat was not determined; thus, the plant density estimated cannot be used to quantify aboveground biomass. Our goal was complete removal of all milfoil in the infestation areas, and quantifying a reduction in biomass was not a project goal.

Between five and eight quadrats were sampled along each transect during each sampling event. Quadrat locations covered by barrier treatment during the course of the project were not sampled, and this accounted for the uneven quadrat numbers among sampling events. For the limited-treatment area, barrier analysis, unpaired $t$ test, comparison of means was used to assess difference in plant density before and after barrier deployment to investigate recolonization rates. 
Table 1. Submerged nonindigenous (NI) aquatic plant-removal schedule at three discrete treatment sites in Emerald Bay Underwater Park, 2010-2015. Limited treatment removed only a portion of the plants in a treatment site-anything less than complete removal of all plants in the discrete site was considered limited treatment. Intensive treatment always included use of all three control methods (barriers, suction removal, and hand removal) in combination to remove all visible plants in a discrete treatment site. Maintenance treatment involved follow-up removal of all recolonizing plants in a discrete treatment site after initial intensive treatment. Barriers were not necessary for maintenance removal. No maintenance removal was necessary in 2015 because there were no NI plants detected in Emerald Bay.

\begin{tabular}{llll}
\hline Year & Vikingsholm & Parson's Rock & Avalanche \\
\hline 2010 & Intensive & Limited & None \\
2011 & Maintenance & Intensive & Limited \\
2012 & Maintenance & Maintenance & Intensive \\
2013 & Maintenance & Maintenance & Intensive \\
2014 & Maintenance & Maintenance & Maintenance \\
2015 & No plants & No plants & No plants \\
\hline
\end{tabular}

Control Methods. Reconnaissance surveys of each site were completed by scuba divers before the initiation of plant-removal activities. We started with an initial intensive treatment, which was followed by maintenance removal each subsequent year (Table 1). Intensive treatment always employed a concurrent combination of control methods: benthic barriers, diver-assisted suction removal, and hand removal. The combined methods were repeated until all visible plants were removed from the discrete infestation area. Barriers were never necessary for maintenance removal, and we were able to complete all maintenance with suction or hand removal.

Benthic barrier treatment consisted of scuba divers placing sections of gas-permeable material (i.e., perforated black plastic or landscape cloth) over the top of the plants to exclude all light. Several different kinds of material can be used as benthic barriers. We tested the cost effectiveness of two benthic-barrier materials: (1) reusable 3.1- by 12.2$\mathrm{m}$ black-plastic Lake Bottom Blankets (Derma-Safe, 32 Juniper Road, Wayne, NJ 07470), and (2) rolls of disposable landscape weed cloth, each measuring 2.4 by $91.4 \mathrm{~m}$. Regardless of the material used, benthic barriers were placed so that individual panels overlapped by 10 to $15 \mathrm{~cm}$ (3.9 to $5.9 \mathrm{in})$ to ensure complete cover and secured to the bottom with rebar. Benthic barriers were left in place for a minimum of $6 \mathrm{wk}$ and not longer than 5 mo because EWM can grow on sediment that accumulates on top of the barriers (Laitala et al. 2012). Many of the Lake Bottom Blankets were reusable, and these were dried, decontam- inated, and stored for later use. The landscape weed cloth could only be used once.

Diver-assisted suction removal efforts focused on areas that were not covered by the barriers because barriers shifted after initial deployment, bottom topography was irregular, or large boulders or wood timbers were present. Suction removal involved scuba divers pulling plants by hand and placing them into a suction hose that transferred the plants to a biomass catch basket positioned on the surface next to a tender boat. Plants were transferred from the basket into garbage cans for off-site disposal. An assistant on the tender boat used a pool net to capture plant fragments generated during suction-removal activities.

Removal by hand was generally the last removal activity employed at each site. In addition, hand removal was used extensively during subsequent maintenance treatment because this method was effective in treating individual or small groups of plants (Bailey and Calhoun 2008). Hand removal involved one or two scuba divers swimming systematically over a treatment site pulling plants by hand and collecting them in a fine-mesh dive bag for later disposal.

\section{Results and Discussion}

This study assessed the efficacy of an integrated NI aquatic-plant treatment strategy, which included (1) a management plan using multiple control methods, along with targeted investigations of pilot treatment, limited and incomplete treatment, material costs, and diver effort, which were used to guide adaptation of the plan; (2) a large initial investment in treatment to completely remove all NI aquatic plants in each EWM/CLP site in Emerald Bay; (3) EDRR to detect and remove new recruits, pioneer plants, and plants missed during previous treatment; (4) detailed mapping and ecological monitoring to provide data and information used to develop the weed-management plan and to document efficacy; and (5) long-term commitment to annual maintenance treatment thereafter. Resource managers can be challenged during implementation of NI aquatic plant control because research findings often need to be synthesized, actions need to be modified to fit local conditions, and long-term research is often not possible because of funding constraints. Collaboration between science and management was necessary to overcome these challenges.

Small-Scale Pilot Testing. Ecological monitoring of a small-scale pilot treatment effort at Parson's Rock, using only a single treatment method, showed that EWM can reestablish in treatment sites to densities comparable to untreated areas within 15 mo after treatment (Figure 3). Analysis by $t$ test showed that barrier treatment alone significantly reduced plant densities from pretreatment in 


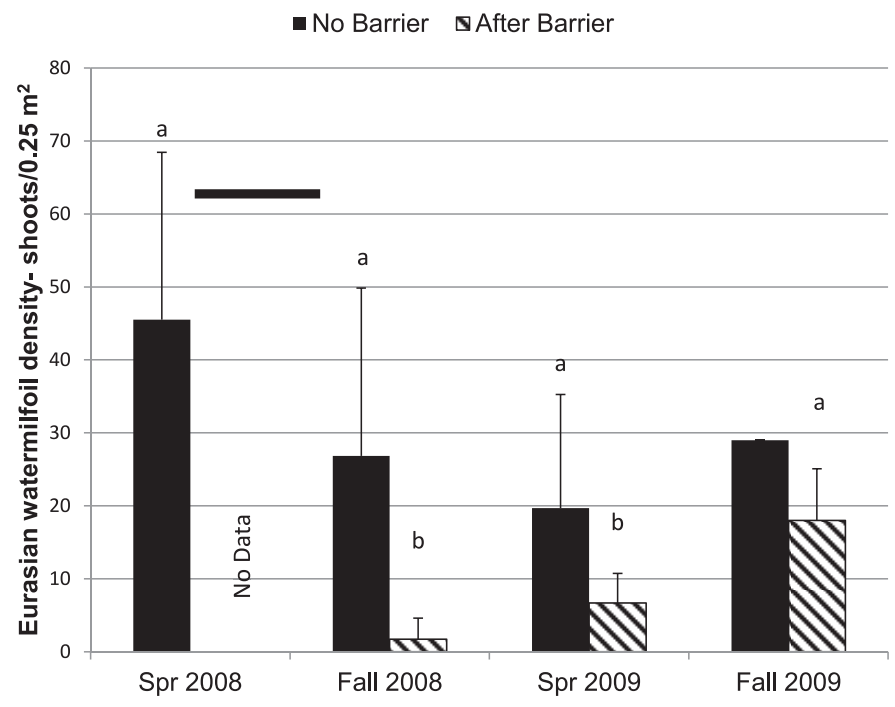

Figure 3. Eurasian watermilfoil plant densities with and without small-scale benthic barrier treatment. Samples were simultaneously collected in areas covered with small (approximately $9 \mathrm{~m}^{2}$ ) barriers (after barrier) and areas not covered with small barriers (no barrier). Values of vertical bars are means of 3 to 6 replicates $\pm 1 \mathrm{SD}$. The horizontal bar depicts the duration of small-barrier deployment between June and September of 2008. Mean values in a column followed by the same letter are not significantly different from the pretreatment sample in spring 2008 (P < 0.05). Only one sample was collected in the fall 2009

"No Barrier" area, and this was not included in the statistical comparison.

spring 2008 compared with fall $2008(\mathrm{P}=0.0153)$ and spring $2009(\mathrm{P}=0.0323)$, but there was no longer a significant difference by fall $2009(\mathrm{P}=0.1621)$. This finding is consistent with past EWM research, which found that treated areas adjacent to untreated sites are prone to rapid reestablishment (Bailey and Calhoun 2008; Boylen et al. 1996; Eichler et al. 1995). In the context of the management plan, these results confirmed that small-scale control efforts using a single-treatment method were unlikely to provide an effective strategy for EWM control in Emerald Bay.

Early, small-scale technique testing highlighted important limitations for each method. Benthic barriers were not able to cover all plants in areas with diverse substrates and submerged obstacles, such as rocks and logs. Suction removal was not completely effective at removing all plants in areas of dense growth because some plants or roots were missed as the water became turbid from disturbing the substrate during removal. Plants have been observed to regenerate if the roots are not completely removed (Bailey and Calhoun 2008). Removal by hand was very labor intensive in areas of dense growth but worked well in locations with sparse cover. Because each of the methods

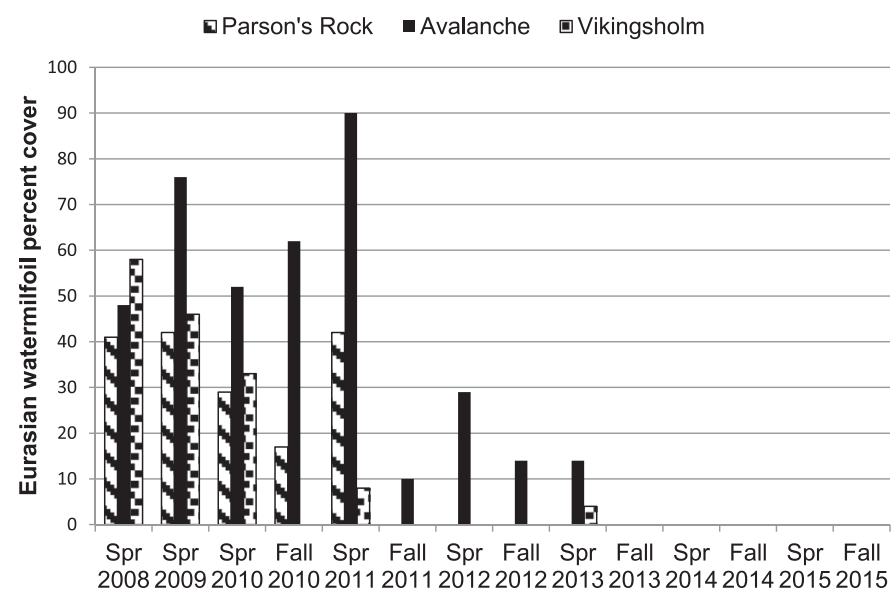

Figure 4. Eurasian watermilfoil percentage of cover at each of the three discrete treatment sites (Parson's Rock, Avalanche, and Vikingsholm).

had specific limitations, all three methods were deployed in combination, concurrently throughout treatment of each discrete site in Emerald Bay.

Limited Control. Because of funding and time constraints, we were only able to conduct limited control work in 2010 at Parson's Rock and in 2011 at Avalanche. These efforts reduced the percentage of cover between the spring and fall transect-monitoring events but did not result in removal of all plants at the site (Figures 4 and 5). A chi-square analysis showed that the combined, limited treatment at Parson's Rock in 2010 and Avalanche in 2011 significantly reduced the percentage of cover from 61.9 to $9.5 \%$ by the fall of the treatment year $(\mathrm{P}<0.0001)$, but by the following spring, the percentage of cover had significantly increased $(\mathrm{P}<0.0278)$ to $30.1 \%$ cover. In contrast, complete treatment and removal of all NI aquatic plants at these sites in the years after the limited treatments resulted in a significant decline $(\mathrm{P}<0.0001)$ from $30.1 \%$ cover to $0 \%$ cover in the fall. By the following spring, cover was still only $3 \%$, and those plants were easily removed during maintenance treatment. In the context of the management plan, the results of these limited treatment efforts reinforced the need for complete removal of all NI aquatic plants at each discrete site during the initial intensive effort. This finding is consistent with previous research that found regrowth if treatment was incomplete (Boylen et al. 1996; Eichler et al. 1995; Kelting and Laxson 2010; Laitala et al. 2012; Panetta 2009).

Barrier Material Comparison. In 2010, we conducted side-by-side treatments using disposable and reusable barrier materials at Vikingsholm (South Lake Tahoe, 


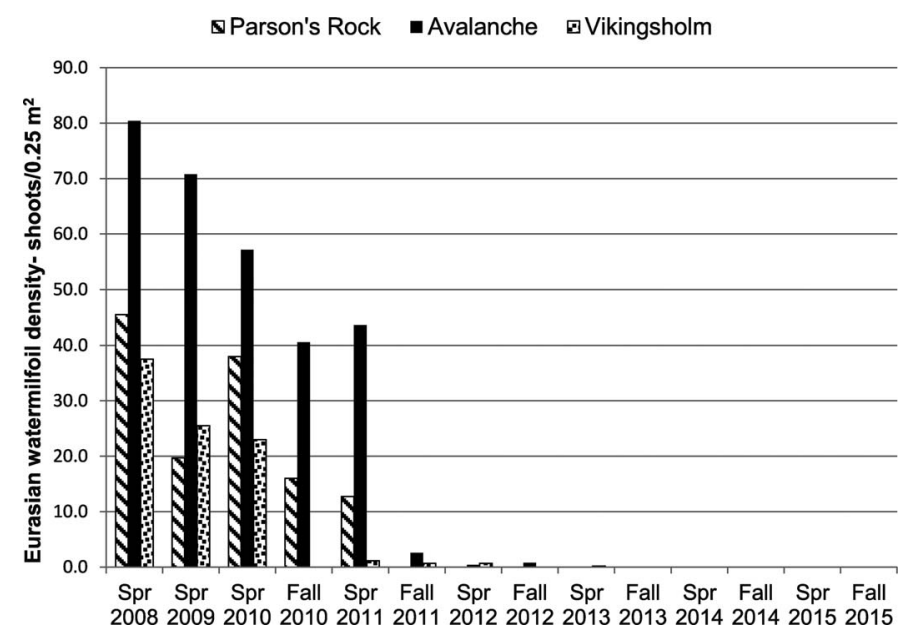

Figure 5. Eurasian watermilfoil plant densities at each of the three discrete treatment sites (Parson's Rock, Avalanche, and Vikingsholm). We counted 1 shoot plant ${ }^{-1}$ cluster to limit scuba dive time.

CA). Together these treatments covered most of the main plant growth at this site. The disposable weed cloth was less costly for materials and labor during the first installation at $\$ 10.61 \mathrm{~m}^{-2}$, compared with $\$ 13.51 \mathrm{~m}^{-2}$ for reusable benthic blankets. However, the reusable benthic blankets became more cost effective during the second installation at $\$ 6.94 \mathrm{~m}^{-2}$, and progressively more cost effective with each successive use. (Note that these cost estimates are from the easy-access Vikingsholm control work, and do not include costs for a boat and increased dive time that would be necessary to treat more-remote sites.) We have reinstalled the reusable benthic barriers for four seasons and have lost $<10 \%$ of the barriers, mostly by damage from boat anchors, so the reusable barriers are proving much more cost effective than one-time use materials.

Diver Effort. There was a steep decline in diver effort necessary to complete maintenance treatment in each successive year to keep sites free of plants (Figure 6). This is consistent with previous research because Kelting and Laxson (2010) found that the EWM maintenance cost was $33 \%$ of the average cost of the initial intensive treatment. We found the diver effort necessary to keep a site free of plants was, on average, only $11 \%$ of the initial treatment effort (Table 1). By 2015, diver maintenance effort was not necessary because there were no NI plants detected at any treatment site. Perhaps the smaller project area and complete plant removal influenced the lower cost for maintenance treatment found in this study. The lack of native, submerged macrophytes may have also reduced maintenance cost because effort was not expended to pick

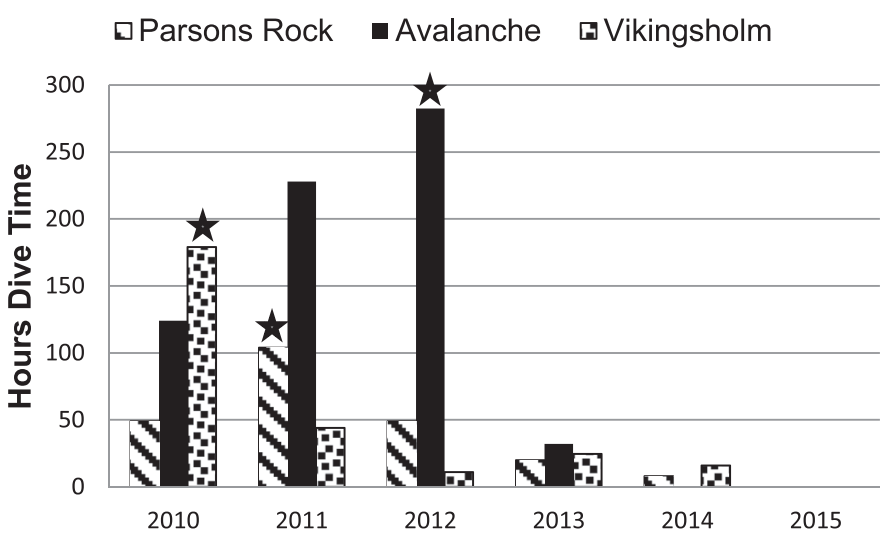

Figure 6. Diver effort in hours of dive time. The star denotes the year when complete intensive treatment was implemented at the Parson's Rock, Vikingsholm, and Avalanche treatment sites.

through native vegetation to find the NI aquatic plants. These results suggest the cost to maintain a site should decline substantially, as long as there is adequate investment in an intensive initial treatment.

Initial Intensive Treatment. Comprehensive treatment at each discrete site in Emerald Bay started with an initial intensive effort to remove every plant, using multiple treatment methods. Repeated treatment of the same area during the initial treatment year was very important, especially when using suction or hand removal because plants were often missed as the sediment was stirred up, and visibility temporarily declined. Vikingsholm was the first discrete infestation intensively treated in 2010, followed by Parson's Rock in 2011, and Avalanche in 2012 to 2013 (Table 1; Figures 4 and 5). We started our initial intensive treatment with Vikingsholm in 2010 because this location receives the highest level of boat traffic because of the pier location and proximity to the mostpopular recreation attractions. Avalanche was much larger and more technically challenging than the other two sites because of the large numbers of submerged logs and rocks, which required us to complete treatment working systematically from the southern to the northern edge of the site over 2 yr (Table 1; Figures 4 and 5). No NI aquatic plants were found during ecological monitoring in the fall at the end of each initial intensive control effort (Figures 4 and 5).

An initial, intensive treatment year was a key priority of our management plan because pilot treatment efforts showed that small-scale treatments using only one method were ineffective, and limited control efforts that did not remove all plants allowed rapid recolonization. Analysis of diver effort showed that future costs declined substantially after the initial large-scale treatment efforts. Ecological 
monitoring documented that our initial intensive removal efforts were successful at removal of all NI aquatic plants by the fall of the treatment year, and that regrowth the following spring was minimal. Together, these findings are important because they inform managers of treatment costs and requirements necessary to achieve complete removal of EWM and CLP. Expending funds on incomplete treatments over multiple discrete infestation areas is not anticipated to be an effective long-term treatment strategy. Expending these same funds on comprehensive treatment of fewer sites appears to be a better management strategy.

Early Detection and Rapid Response. During the course of this project, two new EWM satellite sites were detected. One site was found at the mouth of Eagle Creek between Vikingsholm and Avalanche at the end of 2012 (Figure 2). In 2013, we combined treatment of this new Eagle Creek site with treatment of Avalanche (see above). The second satellite site was to the east of Parson's Rock (Figure 2), in a small, sheltered cove, where boats frequently moor for extended periods. This Parson's Rock East infestation was detected in 2013, and all plants in this $20-\mathrm{m}^{2}$ site were immediately removed by hand. No EWM or CLP plants were detected at this site in 2014 or 2015.

Only one small patch of CLP was detected during baywide surveys of Emerald Bay. This small, approximately 37 $\mathrm{m}^{2}$, patch was found in spring 2009 and was covered with benthic barriers for $4 \mathrm{mo}$ in an attempt to completely eradicate this plant when its coverage was still small. We have not detected any rooted CLP in Emerald Bay since this treatment effort, suggesting the rapid response effort was successful in eradicating this plant. CLP is able to produce vegetative propagules called turions, which can remain in the substrate for future germination. It is possible that our EDRR treatment of this CLP patch was initiated before turion production, and detection and removal of a weed before reproduction is a key to successful eradication efforts (Panetta 2009). However, CLP fragments have been observed floating on the surface of Emerald Bay, so there is a potential for reestablishment as long as boats travelling from other CLP sites in Lake Tahoe enter the bay. Overall, EDRR efforts supported previous research showing that treating a site early, when it is still limited in size, was the most-successful approach to removing EWM and CLP (Rejmanek and Pitcairn 2002).

Maintenance Program. We completed maintenance treatment at Vikingsholm from 2011 through 2014, at Parson's Rock from 2012 to 2014, and at Avalanche in 2014. No maintenance control work was necessary in 2015 because no rooted NI aquatic plants were found in any of the treatment sites. Limited plant cover and density have been detected at Vikingsholm during the maintenance period, suggesting EWM fragments are being reintroduced at this high boat-traffic area. This finding reinforces the need to continually monitor vulnerable areas to keep plants from reestablishing. We were surprised that recolonization by NI aquatic plants was not more frequent because floating fragments are regularly observed in Emerald Bay. It is possible that substantially increasing the nearest-neighbor distance to the next-closest NI aquatic plant site reduced invasion potential. Another possibility is that the initial establishment of NI aquatic plants in Emerald Bay altered substrate or other conditions that stimulated further plant establishment and spread. Removing all NI aquatic plants from Emerald Bay may have reversed those self-supporting changes, so that susceptibility to reestablishment may have been reduced.

Summary. This coordinated, integrated, and long-term management strategy successfully removed $>24,000 \mathrm{~m}^{2}$ (2.4 ha) of submerged aquatic NI plants from Emerald Bay using only physical-control methods and has effectively kept these plants from reestablishing. We continue to observe floating EWM and CLP fragments in Emerald Bay brought in by boats and currents so maintenance, monitoring, and rapid-response treatments will need to continue as long as other areas of Lake Tahoe provide a source of plants to reinfest Emerald Bay. This case study found that (1) successful NI plant control requires a high initial investment; (2) investment costs decline steeply over time if the initial treatment is effective and maintenance control is completed annually; (3) multiple and integrated physical-treatment methods can be successfully used to control NI aquatic plants; (4) partial or incomplete treatment areas are quickly recolonized and are likely not worth the investment; (5) early detection and rapid response are essential, especially in locations in which there is a substantial risk of reintroduction; (6) ecological monitoring needs to be incorporated to assess and adjust control actions; and (7) a long-term commitment is necessary. Although this management strategy requires substantial commitment and resources, elimination of portions of the plan could limit effectiveness and increase costs over time.

\section{Acknowledgments}

The dedication and attention to detail of S. and A. Murphy (Wet Leprechaun Dive Services, 1509 Church Street, Gardnerville, NV 89410-5120), and ACE Diving (6959 West Maine Street, Spirit Lake, ID 83869) made this effort possible. Special thanks to D. Jaffke and the California State 
Parks Dive Team; M. Wittmann, K. Boyd, J. Brockett, N. Cartwright, B. Allen, and A. Lewis; and the Tahoe Resource Conservation District, Tahoe Regional Planning Agency, Lake Tahoe Aquatic Invasive Species Program, and California State Lands Commission. Funding for this project was provided by the Proposition 84 Clean Water, Parks, and Coastal Protection Act, Southern Nevada Public Lands Management Act, the U.S. Bureau of Reclamation-Wetlands Restoration Program, California State Lands Commission, and California State Parks.

\section{Literature Cited}

Anderson LWJ (2006) Survey of Lake Tahoe for Aquatic Plants, 19952005: Unpublished Annual Reports 1995-2006, Davis, CA. Davis, CA: USDA-ARS Aquatic Weed Control Research Laboratory, University of California, Davis

Barko JW, Smart RM (1980) Mobilization of sediment phosphorus by submersed freshwater macrophytes. Freshwater Biol 10:229-238

Bailey JE, Calhoun AJK (2008) Comparison of three physical management techniques for controlling variable-leaf milfoil in Maine lakes. J Aquat Plant Manag 46:163-167

Boylen CW, Eichler LW, Madsen JD (1999) Loss of native aquatic plant species in a community dominated by Eurasian watermilfoil. Hydrobiologia 415:207-211

Boylen CW, Eichler LW, Sutherland JW (1996) Physical control of Eurasian watermilfoil in an oligotrophic lake. Hydrobiologia 340:213-218

Bremigan MT, Hanson SM, Soranno PA, Cheruvelil KS, Valley RD (2005) Aquatic vegetation, largemouth bass and water quality responses to low-dose fluridone two years post treatment. J Aquat Plant Manag 43:65-75

Coats R, Perez-Losada J, Schladow G, Richards R, Goldman C (2006) The warming of Lake Tahoe. Clim Change 76:121-148

Eichler LW, Bombard RT, Sutherland JW, Boylen CW (1993) Suction harvesting of Eurasian watermilfoil and its effect on native plant communities. J Aquat Plant Manag 31:144-148

Eichler LW, Bombard RT, Sutherland JW, Boylen CW (1995) Recolonization of the littoral zone by macrophytes following the removal of benthic barrier material. J Aquat Plant Manag 33:51-54

Eiswerth ME, Donaldson SG, Johnson WS (2000) Potential environmental impacts and economic damage of Eurasian watermilfoil (Myriophyllum spicatum) in western Nevada and northeastern California. Weed Technol 14:511-518

Elzinga CL, Salazar DW, Willoughby JW (2001) Measuring and Monitoring Plant Populations. Denver, CO: Bureau of Land Management Technical Reference 1730-1. 496 p

Engel S (1984) Evaluating stationary blankets and removable screens for macrophyte control in lakes. J Aquat Plant Manag 31:144-148

Goldman CR (1988) Primary productivity, nutrients, and transparency during the early onset of eutrophication in ultra-oligotrophic Lake Tahoe, California-Nevada. Limnol Oceanogr 33:1321-1333

Halstead JM, Michaud J, Hallas-Burt S, Gibbs JP (2003) Hedonic analysis of effects of a nonnative invader (Myriophyllum heterophyllum) on New Hampshire (USA) lakefront properties. Environ Manag 32:391-398

Heyvaert AC, Reuter JE, Chandra S, Susfalk RB, Schladow SG, Hackley SH (2013) Lake Tahoe Nearshore Evaluation and Monitoring
Framework: Final Report Prepared for the USDA Forest Service Pacific Southwest Research Station. Davis, CA: Nearshore Agency Working Group.

Horsch EJ, Lewis DJ (2008) The effects of aquatic invasive species on property values: evidence from a quasi-experiment. Land Econ 85:391-409

Kamerath M, Chandra S, Allen B (2008) Distribution and impacts of warm water invasive fish in Lake Tahoe, CA-NV, USA. Aquat Invasions 3:35-41

Kelting DL, Laxson CL (2010) Cost and effectiveness of hand harvesting to control the Eurasian watermilfoil population in Upper Saranac Lake, New York. J Aquat Plant Manag 48:1-5

Kim JG., Rejmankova E (2001) The paleoecological record of human disturbance in wetlands of the Lake Tahoe Basin. J Paleolimnol 25:437-454

Laitala KL, Prather TS, Thill, Kennedy DB, Caudill C (2012) Efficacy of benthic barriers as a control measure for Eurasian watermilfoil (Myriophyllum spicatum). Invasive Plant Sci Manag 5:170-177

[LRWQCB] Lahontan Regional Water Quality Control Board (1995) Water Quality Control Plan for the Lahontan Region, North and South Basins (Basin Plan). South Lake Tahoe, CA: California Regional Water Quality Control Board, Lahontan Region

Landers DH (1982) Effects of naturally senescing aquatic macrophytes on nutrient chemistry and chlorophyll $a$ of surrounding waters. Limnol Oceanogr 27:428-439

Lindenmayer DB, Likens GE (2010) The science and application of ecological monitoring. Biol Conserv 143:1317-1328

Loeb SL, Hackley SH (1988) The distribution of submerged macrophytes in Lake Tahoe, California and Nevada, and the possible influence of groundwater seepage. Mitt Int Ver Theor Angew Limnol 23:1927-1933

Madsen JD (1997) Methods for management of nonindigenous aquatic plants. Pages 145-171 in Luken JO, Thieret JW, eds. Assessment and Management of Plant Invasions. New York: Springer

Madsen JD, Sutherland JW, Bloomfield JA, Eichler LW, Boylen CW (1991) The decline of native vegetation under dense Eurasian watermilfoil canopies. J Aquat Plant Manag 29:94-99

[NISC] National Invasive Species Council (2003) General Guidelines for the Establishment and Evaluation of Invasive Species Early Detection and Rapid Response Systems. Version 1. Washington, DC: National Invasive Species Council, U.S. Department of the Interior. $16 \mathrm{p}$

[NPS] National Park Service (2014) National Natural Landmarks Program. http://www.nature.nps.gov/nnl/. Accessed September 23, 2014

Panetta FD (2009) Weed eradication: an economic perspective. Invasive Plant Sci Manag 2:360-368

Parsons J (2001) Aquatic Plant Sampling Protocols. Washington State Dept Ecol Publ No 01-03-017 https://fortress.wa.gov/ecy/ publications/publications/0103017.pdf. Accessed March 20, 2016

Perkins MA, Boston HL, Curren EF (1980) The use of fiberglass screens for control of Eurasian watermilfoil. J Aquat Plant Manag 18:13-19

Rejmanek M, Pitcairn MJ (2002) When is eradication of exotic pest plants a realistic goal? Pages 249-253 in Veitch CR, Clout MN, eds. Turning the Tide: The Eradication of Invasive Species. Auckland, New Zealand: Invasive Species Specialist Group of the World Conservation Union (IUCN)

Reylea RA (2005) The impact of insecticides and herbicides on the biodiversity and productivity of aquatic communities. Ecol Appl $15: 618-627$

146 - Invasive Plant Science and Management 9, April-June 2016 
Relyea RA, Hoverman JT (2006) Assessing the ecology in ecotoxicology: a review and synthesis in freshwater systems. Ecol Lett 9:1157-1171

Reuter JE, Thomas JM, Heyvaert AC (2009) Water quality. Pages 83182 in Hymanson, ZP, Collopy MW, eds. An Integrated Science Plan for the Lake Tahoe Basin: Conceptual Framework and Research Strategies. Albany, CA: U.S. Department of Agriculture General Technical Report PSW-GTR-226

Sahoo GB, Forrest AL, Schladow SG, Reuter JE, Coats R, Dettinger M (2016) Climate change impacts on lake thermal dynamics and ecosystem vulnerabilities. Limnol Oceanogr 61:496-507

Smith CS, Adams MS (1986) Phosphorus transfer from sediments by Myriophyllum spicatum. Limnol Oceanogr 31:1312-1321

Smith CS, Barko JW (1990) Ecology of Eurasian watermilfoil. J Aquat Plant Manag 28:55-64

Tucker AJ, Williamson CE, Rose KC, Oris JT, Connelly SJ, Olson MH, Mitchell DL (2010) Ultraviolet radiation affects invasibility of lake ecosystems by warm-water fish. Ecology 91:882-890
Wagner KJ, Mitchell DF, Berg JJ, Gendron WC (2008) Milfoil Ecology, Control, and Implications for Drinking Water Supplies. Denver, Co: AWWA Research Foundation. 217 p

Walter K (2000) Ecosystem Effects of the Invasion of Eurasian watermilfoil (Myrophyllum spicatum) at Lake Tahoe, CA-NV. M.S. thesis. Davis, CA: University of California

Wittmann ME, Kendall BE, Jerde CL, Anderson LWJ (2015) Estimating relative risk of within-lake aquatic plan invasion using combined measures of recreational boater movement and habitat suitability. PeerJ 3:e845. DOI: 10.7717/peerj.845

Zhang C, Boyle KJ (2010) The effect of an aquatic invasive species (Eurasian watermilfoil) on lakefront property values. Ecol Econ 70:394-404

Received January 15, 2016, and approved April 6, 2016.

Associate Editor for this paper: Ryan M. Wersal, Lonza Specialties Ingredients 